\title{
REFORM OF RETIREMENT PROGRAMS AND THE FUTURE WELL-BEING OF THE ELDERLY IN AMERICA
}

\author{
by \\ Robert L. Clark \\ and \\ Joseph F. Quinn
}

Paper Prepared for Sixth International Research Seminar
On Issues in Social Security Sponsored by
Foundation for International Studies on Social Security

Sigtuna, Sweden

June 1999

This paper is based on a longer study "Can Adverse Effects of Reductions in Medicare Be Offset by Improvements in Other Retirement Programs?" prepared for the National Academy of Social Insurance, January 1999. 


\section{INTRODUCTION}

In developed countries, persons aged 65 and older depend on a variety of public and employer-provided retirement programs for much of their income. Many retirees supplement benefits from these retirement programs with earnings and asset income while others rely almost entirely on the government retirement programs. The continued aging of national populations is increasing the cost of providing income and medical services to older persons. As a result, reform of Social Security retirement and health care programs is among the most important public choices now facing the countries of Europe and North America.

This paper examines how the various public and private retirement programs in the United States are under increasing financial pressure stemming from the aging of the population. We document trends in the cost of these programs, proposals for their reform, and assess the future impact of changes on the economic well-being of America's elderly. We begin with a brief overview of the economic well-being of the elderly and the importance of various income sources for retirement age individuals. Next, we assess the changing status of each of the major programs providing benefits to older Americans and how they are likely to interact in the future.

\section{ECONOMIC STATUS OF THE ELDERLY}

The average economic status of America's elderly has improved significantly over the past 30 years. Despite the impressive improvement in their average economic wellbeing, however, the elderly are disproportionately represented among the near-poor and certain older Americans (the less educated, those living alone, and the oldest of the old) still face substantial risk of economic deprivation.

Income of the Elderly. Examining gains in median income from 1969 to 1996 for all American households and separately for 12 different household types shows the dramatic gains in economic well-being for the elderly. Of the 12 demographic categories, 
three types of elderly households (elderly couples, single men, and single women) had the largest increases in median incomes over the 27 year period, about 60 percent in real terms, with most of the improvement occurring by the mid-1980s (McNeil, 1998).

In contrast, the median income of married couples with children rose by about 25 percent, while that of married couples (aged less than 65) without children and women under age 65 living along rose by about a third. For female householders with children and no spouse and for males under age 65 living along, the gain was close to 10 percent. The absolute and relative gains in elderly family income are even more impressive because they occurred while the labor force participation rates and hence annual earnings of older men were declining. ${ }^{1}$

Since 1979, the Census Bureau has produced an expanded definition of income that begins with cash income, subtracts payroll and income taxes, and adds capital gains, earned income tax credits, non-cash income (such as the value of Medicaid and Medicare coverage, and health insurance supplements to wages) and an imputed return on home equity (U.S. Bureau of the Census, 1992). Between 1979 and 1996, there was no net change in the median real cash income of all American households while the elderly's median income increased by 13 percent. Using the broader measure of income, the median real income of all households rose by almost 5 percent from 1979 to 1996 compared to a 20 percent increase for the elderly groups. Using this broader measure of income strengthens the conclusion that increases in the real income of the elderly have greatly exceeded those of the rest of the population.

One of the most noteworthy domestic accomplishments of the past three decades has been the dramatic decrease in poverty among American elderly. In 1966, the poverty rate among American elderly was 29 percent compared to 15 percent for the population as a whole and 18 percent for children under age 18 (U.S. Bureau of the Census, 1997). Following large increases in real Social Security benefits in the late 1960s and early 1970s, the elderly poverty rate plummeted, falling from about 25 percent during 1968-1970 to only 
14 percent by 1977 . By 1982 , the elderly poverty rate was below that for the population as a whole, and it has remained below the aggregate rate ever since. In 1996, the elderly poverty rate was 3 percentage points below that of the general population. ${ }^{2}$ In contrast to the improvement in the elderly poverty rate, the proportion of children under age 18 who are in households below the poverty level has increased, exceeding 20 percent for most of the 1990s.

Sources and Shares of Income of the Elderly. Older persons receive income and inkind benefits from government programs, from past and current employers, from their families, and from their own past savings and investments. The most common source of income for the elderly is the Old-Age, Survivors, and Disability Insurance program (referred to as Social Security throughout this paper). Over 91 percent of Americans aged 65 or over received Social Security benefits in 1996 (Grad, 1998). The next most frequently received source is income from assets (interest, dividends, rents and royalties) with about two-thirds of all elderly receiving income from assets in 1996. Employer pension benefits were received by about 40 percent of elderly households. Pension receipt declines with age, dropping from about 45 percent of those aged 65 to 74 years to only 30 percent of those aged 85 or older. About one in five older Americans is still employed, a ratio that drops from 4 in 10 for those 65 to 69 years of age to only 4 in 100 for persons aged 85 and older. Veterans' benefits and public assistance (primarily the means-tested Supplemental Security Income) are received only by about 5 percent of persons aged 65 and older.

Older Americans derive 40 percent of their total cash income from Social Security, about 20 percent each from employer pensions, income from assets, and earnings, and a small residual from all other sources, including public assistance (Grad, 1998). ${ }^{3} \quad$ The relative importance of these income sources differs dramatically by the age and income status of the recipient. The share of total income from Social Security in 1996 increased from about 30 percent for those aged 65 to 69 to well over half for those aged 80 or older. 
Earnings shares drop over the same age range, from about a third of total income for those aged 65 to 69 , to about 10 percent for those aged 75 to 79 , and only 6 percent for those aged 80 or older. The shares from asset income and employer pensions are more stable with age.

For the poorest 40 percent of older Americans, Social Security benefits provided over 80 percent of all cash income in 1996 (Grad, 1998). For the lowest quintile, public assistance provided another 11 percent, leaving only 8 percent from all other sources including earnings and pension benefits. Among those in the bottom two quintiles, over 85 percent of the aged units received more than half of their income from Social Security and over 50 percent received more than 90 percent of their income from Social Security. In contrast, for those in the highest 20 percent of the income distribution, earnings was the primary income source of income (providing 31 percent of income), followed by income from assets, Social Security, and employer pension benefits (between 20 and 25 percent each).

Wealth Distribution of the Elderly Population. Wealth is an important component of economic well-being. The primary component of wealth in the U.S. is home equity. The wealth holdings of Americans are more unevenly distributed across households than annual income and more so than in other industrialized nations. The wealthiest one percent of all Americans held over 38 percent of all household wealth (or net worth) in 1995, and the top 20 percent of richest Americans held 84 percent of all wealth (Wolff, 1998). Both of these percentages are higher than they were in the early 1980s, indicating that wealth inequality is increasing. For financial wealth, which excludes home equity, the top one and top 20 percent of households hold even larger proportions of aggregate wealth (47 and 93 percent of all financial wealth in 1995, respectively) and both of these percentages have increased since the early 1980 s.

A Population At Risk? There is much reason for optimism as we consider the economic well-being of retirees in the Twenty-First century. Life expectancy continues to 
increase and evidence suggests that older Americans are also healthier than earlier cohorts. The nation as a whole has grown more prosperous. Real per capita output in the U.S. doubled between 1960 and 1995 and at a two percent real growth rate, would double again by the year 2030. Workers today are accumulating more assets relative to their earnings than their parents did (Sabelhaus and Manchester, 1995).

The economic circumstances of older Americans have improved dramatically over the past three decades, even more so than for the rest of the population. Real incomes of the elderly have risen and poverty rates declined. Future retirees will be much better educated than today's older Americans.

Beneath this generally rosy outlook, however, are serious concerns. Although the elderly today are less likely than the average citizen to be poor, they remain disproportionately represented among the near poor (i.e. under 125 to 150 percent of the poverty threshold). Growth in employer pension coverage has stalled at approximately half of the labor force since the mid-1970s (EBRI, 1997). The relative size of some traditionally vulnerable groups (minorities and older women) is increasing. A higher proportion of future retirees are likely to be living alone in old age compared to their parents due to a lower marriage rate, a higher divorce rate, and a lower fertility rate among current workers (AARP, 1998).

Two factors that significantly improved the retirement income of current retirees are unlikely to reoccur: the dramatic run-up in asset prices during the two decades prior to retirement and the increases in real Social Security benefits legislated before they retired. In fact, it is quite likely that the reverse will happen for persons retiring in the next 30 years, i.e. a decline in asset prices as the relatively large cohort of future retirees sell the assets they have accumulated for retirement (Schieber and Shoven, 1997) and a decrease or delay in Social Security benefits.

Finally, personal wealth is inadequate for persons most at risk of falling into poverty in old age. There is some debate about whether baby boomers on average are 
saving enough to maintain their standards of living in retirement, but there is no reason for optimism about the bottom half of the income distribution, especially those in poor health. Their housing equity is modest, and their financial reserves beyond home equity are almost non-existent.

It is important to recognize that people can adjust to changing economic circumstances that adversely affect their well-being. Many Americans will continue to approach traditional retirement ages employed and in good health with many years of life expectancy ahead of them. If early retirement is expected to result in inadequate income, then the easiest adjustment to potential economic distress for healthy older persons would be to alter their retirement plans. Older Americans may decide to work longer in the future and use earnings to augment their "retirement" income.

In the Twenty-First century, there will continue to be a portion of the elderly population who will be at serious risk of living the last years of their lives in poverty. Among the most vulnerable are persons living alone, the oldest old, the poorly educated, and those without housing equity. It is likely that older women, especially minority women, will have the highest poverty rates. Their incomes and assets will be inadequate to meet their normal needs, and completely inadequate to handle the expenses of a catastrophic illness or long term care. Future changes in retirement income and health policies must be carefully examined for their impact on these at risk populations.

\section{PUBLIC RETIREMENT PROGRAMS IN THE TWENTY-FIRST CENTURY}

Two public income maintenance programs that affect the economic well-being of elderly Americans are Social Security and Supplemental Security Income (SSI) while Medicare and Medicaid provide health care benefits to elderly households. Despite the fact that it reaches only 6 percent of elderly households, SSI is an important component of retirement income for low income elderly. Medicare provides comprehensive health insurance for most Americans 65 and older while Medicaid also provides considerable 
assistance to low income families. Prospective changes in Social Security, SSI, Medicare, and Medicaid are now examined to determine how these programs might respond to the financial challenges associated with population aging and to illustrate how these important programs are interrelated in terms of governmental budgets and eligibility.

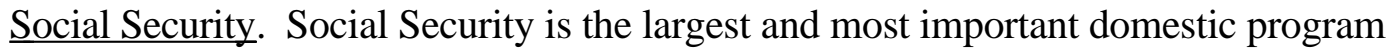
in the United States. It is the largest item in the Federal budget and Social Security expenditures represent an increasing part of total national income. In 1998, 44.2 million Americans received Social Security benefits and OASDI expenditures represented approximately one-quarter of the federal budget (Board of Trustees, OASDI, 1999 and U.S. Office of the President, 1999). ${ }^{4}$

Social Security contains a strong income redistributional component. The progressivity of Social Security is due to the formulas used to calculate retirement benefits. The Primary Insurance Amount (PIA), the amount a worker receives if benefits are claimed at the normal retirement age of 65 , is a concave function of lifetime average indexed monthly earnings (AIME). ${ }^{5}$ Thus, the replacement rate from Social Security declines as lifetime earnings increase.

Social Security is clearly the most important income source for low and moderate income elderly families. As such, it offers the possibility of offsetting potential cuts in Medicare and other retirement programs. Unfortunately, Social Security is also threatened by the aging of the population and must itself be reformed in the near future. The nature of these reforms is of central importance in determining the economic well-being of future retirees.

Over the next 75 years, Social Security expenditures are projected to exceed revenues by 2.07 percent of covered payroll. ${ }^{6}$ Cash flow surpluses until the year 2022 will increase the OASDI trust fund to nearly \$4.5 trillion, in nominal dollars. These accumulated reserves will then be depleted as they are used to offset the negative cash flows resulting from the retirement of the early baby-boom cohorts. If current law is 
maintained, the OASDI reserves are projected to be exhausted by 2034 , at which time Social Security would have annual revenues equal to only about three-quarters of their annual expenditures (Board of Trustees, OASDI, 1999). In the absence of modifications in Social Security, annual deficits continue to rise to over 6.4 percent of payroll in the second half of the Twenty-First century. The financial problems facing Social Security are attributable primarily to the aging of the population and the decline in the ratio of workers to retirees. Current projections indicate that the number of workers per beneficiary will decline from 3.4 in 1999 to 1.8 in 2073 and that OASDI expenditures as a percent of GDP will increase from 4.46 percent in 1999 to 7.04 percent in 2073.

Without significant modifications, Social Security will be unable to pay in full the benefits promised to future retirees. Social Security will not be allowed to default on its obligations and therefore, Social Security reform is inevitable. Some combination of legislated revenue increases, benefit cuts, or delays in the age of early or normal benefit eligibility will occur if the basic structure of Social Security is maintained. Alternatively, a fundamental restructuring of the Social Security system may be enacted. The issue is not whether reform will occur, but rather when it will occur and what form it will take. Most analysts prefer that reform legislation and implementation take place sooner rather than later. There is much less consensus among policy analysts, interest groups, and elected officials on what type of Social Security reforms should be enacted.

Over the past five years, numerous reform plans have been proposed by various individuals, groups, study commissions and councils, and legislators. In general, the proposals can be sorted into two types: (1) retain the current structure of Social Security and make enough minor alterations in benefits and/or revenues to restore financial balance to the system for at least the next 75 years and (2) scrap the current system and replace it with a two tier plan. Most proposals of the second type call for the first tier to provide a minimum benefit to all retirees unrelated to their past earnings and a second tier would consist of individual savings accounts mandated for all workers. 
Despite the wide variety of Social Security reform proposals, several conclusions seem likely. First, the aging of the population threatens the financial security of the current Social Security program. Second, most proposals would result in lower benefits and/or higher lifetime taxes. Therefore, changes in Social Security are more likely to exacerbate rather than offset the adverse effects of potential reductions in other retirement programs on the economic well-being of the elderly.

In his 1998 State of the Union address, President Clinton suggested another method of restoring financial balance to the Social Security system. He proposed allocating 62 percent of the federal budget surpluses projected for the next 15 years ( $\$ 2.8$ trillion) to Social Security. In essence, the President's proposal would allocate future general tax revenues to the Social Security trust fund. The goal of this plan is not to increase future Social Security benefits above what is now promised, but instead to prevent the benefit cuts, benefit delays, or payroll tax increases that might otherwise be necessary. If these optimistic budget surplus forecasts are realized and the majority of these funds are allocated to Social Security, future retirees will enjoy benefits similar to those now promised. The low earners at risk from Social Security, Medicare, or Medicaid reform are the same people with little or no savings and low likelihood of pension coverage. Thus, a key element in the debates over how to reform Social Security must include an assessment of the impact on the income of low income retirees. Future policy debates should consider the interactive impact of changes in both Social Security and Medicare.

Supplemental Security Income. Aged, blind and disabled persons may also receive benefits under the Supplemental Security Income (SSI) program, a federally administered, means-tested public assistance program for the poor. ${ }^{7}$ SSI guarantees a minimum income for eligible recipients and for persons aged 65 or older and often acts as a supplement to Social Security benefits for the poorest elderly. Federal SSI payments are financed by general revenues. Individual states have the option of supplementing the federal SSI benefits and 43 of the 50 states provide additional SSI benefits. 
Although a relatively minor source of income for the elderly overall, public assistance is important to the economic well-being of the poorest of the elderly, especially the nonmarried. In 1996, public assistance (most of which is SSI for those aged 65 or older) was received by about 20 percent of aged units in the lowest income quintile and provided 11 percent of the aggregate income for all older persons in this lowest quintile and 14 percent of the aggregate income of nonmarried elderly (Grad 1998). Elderly SSI recipients are disproportionately non-white and female. The current relationship between SSI and Social Security means that, for dual recipients, decreases in Social Security benefits would be automatically offset by increases in SSI benefits. However, higher SSI costs may result in further review of this program.

Medicare. Medicare provides a minimum level of health insurance to virtually all Americans age 65 and over and is a key element in the economic well-being of older households. Established in 1965, Medicare consists of two components, the Health Insurance (HI) program financed by payroll taxes and the Supplementary Medical Insurance (SMI) program financed by individual premiums and general revenues. Together these programs provide an average benefit to enrollees of $\$ 5,535$ per year and play a central role in providing adequate income and health care in retirement. ${ }^{8}$

The HI program provides insurance coverage for the costs of hospital and certain other medical care services to approximately 33 million aged and 5 million disabled beneficiaries. In 1998, HI expenditures totaled $\$ 135.8$ billion and incomes exceeded expenditures by $\$ 4.8$ billion. As a result, the $\mathrm{HI}$ trust fund increased from $\$ 115.6$ billion at the end of 1997 to $\$ 120.4$ billion at the end of 1998 . Current projections indicate that the HI trust fund will be depleted in 2015 (Board of Trustees, Federal Hospital Insurance Trust Fund, 1999). SMI covered 32 million aged and 4 million disabled persons who chose to enroll in the program. In 1998, SMI expenditures totaled $\$ 77.6$ billion (Board of Trustees, Supplementary Medical Insurance Trust Fund, 1999). 
Expenditures for both parts of Medicare have been increasing rapidly and costs are expected to continue to increase at a rate greater than the growth of national income. As a result, these programs are consuming an ever increasing proportion of the federal budget and of national income. As a fraction of Gross Domestic Product (GDP), HI expenditures are projected to increase from 1.56 percent in 1999 to 2.20 percent in 2025 and further to 3.06 percent in 2073. SMI expenditures are projected to increase from 0.98 percent of GDP in 1999 to 2.23 percent in 2025 and further to 2.65 percent in 2073 . Thus, future expenditures for both parts of Medicare are projected to equal 5.71 percent of GDP in the second half of the Twenty-First century compared to only 2.54 percent of GDP in 1999.

The escalation in the cost of Medicare is the result of both economic and demographic trends. Principally, these are increases in the price of medical services that exceed the rate of growth in the Consumer Price Index (CPI) and the aging of the population. The introduction of new medical technologies and the increased utilization of services continues to push up the price for medical care at a rapid rate thus increasing the cost of providing specified coverage per beneficiary over time. The aging of the population increases the number of beneficiaries relative to the working population. Projections indicate that the number of workers per HI beneficiary will be 3.6 in 2010 when the baby boom cohort begins reaching age 65 and will then fall to 2.3 workers per beneficiary by 2030 (Board of Trustees, Federal Hospital Insurance Trust Fund, 1999).

Aggregate real Medicare expenditures will increase as the nation ages, especially if medical costs rise faster than the general cost of living. The impact of these changes is clear $\tilde{\mathrm{n}}$ if access to services is maintained at current levels, sharp increases in the tax rates will be necessary to finance Medicare. Alternatively, the protection that Medicare provides to older persons could be reduced. Because of the rapid increase in the cost of Medicare, HI and SMI have been a major focus for budget reductions every year since 1980 (Moon, 1996). 
Despite periodic attempts to slow the pace of cost increases, Medicare continues to face significant financial problems. As a result, reductions in medical insurance seem likely as the baby boom cohort approaches age 65 and Medicare eligibility. It is important to examine possible changes in Medicare and how they will affect various types of older households. If Medicare is substantially reduced, will future retirees have the resources to offset or mitigate the adverse effects of these cutbacks?

Medicaid. Medicaid is a federal-state program that provides medical assistance to some low-income persons, including children and pregnant women, the disabled, and the elderly. In recent years, the federal share of total Medicaid costs has been about 56 percent. Over 60 percent of the total Medicaid expenditures for the aged are for care in skilled nursing facilities with another 8 percent each going to home health services and prescription drugs (U.S. House, 1998: Table 15-22).

States are required to provide Medicaid coverage to some groups and are allowed to extend coverage to some other types of low-income persons. Within federal guidelines, states have considerable discretion to establish eligibility conditions, the scope of benefits, and the amount of payments for particular services. The extent of state discretion has grown in recent years. Traditionally, Medicaid coverage was automatic for people deemed "categorically needy" under some other public assistance program. For example, prior to 1996, all AFDC recipients were eligible for Medicaid. After 1996, the automatic link between welfare and Medicaid was broken. However, Medicaid eligibility was mandated for those who met the AFDC requirements in effect in the state in July, 1996, even if these people were not currently eligible for benefits. In 1995, Medicaid covered only 45 percent of the poor in America, only 30 percent of the elderly poor, and only 9 percent of all of the elderly. Coverage is even lower for the near poor and only 16 percent of the elderly with incomes between 100 and 133 percent of the poverty line and only 8 percent of those between 133 and 185 percent of the threshold currently have Medicaid coverage (U.S. House, 1998: table 15-12). 
State Medicaid programs are also required to pay some of the medical expenditures of some of those eligible for Medicare. For example, states must pay all Medicare premiums, deductibles or coinsurance expenses of qualified Medicare beneficiaries (QMBs), those aged and disabled Medicare recipients whose income falls below the poverty line and whose assets are less than twice the SSI threshold. States must also cover all or part of the Part B Medicare premiums of "specified low-income Medicare beneficiaries" including those with less than twice the SSI threshold assets and with income between 100 and 175 of the poverty level, too high for the more generous QMB coverage. Through Medicaid, these programs introduce a needs-based component to the otherwise income-neutral Medicare program. Depending on how regulations develop in the future, state Medicaid programs, with financial backing from the Federal government, have the potential of compensating some of the losses that might occur under future Medicare cutbacks. However, the rapidly rising cost of this program has made it a target of on-going changes to reduce its rate of growth.

\section{EMPLOYER PROVIDED RETIREMENT PROGRAMS IN}

\section{THE TWENTY-FIRST CENTURY}

Many employers provide deferred compensation in the form of pension benefits and retiree health insurance to workers who have met minimum service criteria. Pension benefits are an important source of income to many older families and often are necessary if a household is to continue its pre-retirement standard of living during the retirement years. Employer provided retiree health insurance is an important noncash benefit for many retirees. With public retirement programs likely to provide lower benefits in the future, can company provided benefits offset these expected reductions?

Pension Benefits. Pensions are offered by many employers as part of labor compensation because they help firms attract and maintain quality workers. Workers desire employer provided pensions primarily because of the tax advantages associated with this 
type of retirement savings and the ease of saving prior to receiving the money in their paychecks. The proportion of the labor force covered by some type of employer provided pension rose rapidly from 1950 until 1975 when about half of the labor force was included in an employer pension. Since 1975, the percent of the labor force covered by a pension has remained relatively stable with coverage falling slightly in the 1980 s before increasing slightly in the 1990s.

Participation rates increase with job tenure, age, and annual earnings. These relationships suggest that as workers age, acquire more tenure, attain better jobs, and have higher earnings, the likelihood that they will be included in an employer pension plan increases. Union members are much more likely to participate in a pension plan than nonunion workers. Big companies were much more likely to offer pension plans than small companies. Part-time workers are less likely to be covered by a pension than fulltime employees while government employees are more likely to participate in a pension than workers in the private sector (EBRI, 1994).

Pension plans are of two basic types: defined benefit and defined contribution. In a defined benefit plan, workers are promised a specific benefit in retirement, usually based on years of service times a percent of average salary during the final working years. Defined contribution plans provide for periodic contributions into an individual pension account for each worker. The contributions may be made by the firm and/or the worker. The eventual retirement benefit is dependent on the amount of the contributions and the rate of return on the individual's retirement assets.

Historically, the defined benefit plan was the primary type of pension plan offered by employers; however, in the past two decades, there has been a dramatic shift toward greater utilization of defined contribution plans. ${ }^{9}$ The decline in utilization of defined benefit plans has resulted from increased government regulation that has raised the administrative cost of defined benefit plans and the introduction of new types of defined contribution plans such as the 401(k) plans (Clark and McDermed, 1990). ${ }^{10}$ 
The most rapidly growing type of pension plan is the 401(k) plan. These plans allow workers to make pre-tax contributions to a retirement savings account. In 1983, only 7 percent of private wage and salary workers were offered a 401(k) plan but this proportion increased to 25 percent in 1988 and further to 35 percent in 1993 (U.S. Department of Labor, 1994). In 1993, approximately two thirds of all persons offered such a plan chose to participate.

In most 401(k) plans, workers must decide whether to make voluntary contributions to the plan and how much to contribute. If the worker makes a contribution, many companies then provide some employer matching of the employee contribution. Having contributed to the $401(\mathrm{k})$ plan, the employee then must decide how to invest the funds. Typically, plan sponsors provide a variety of investment options including fixed income securities and equities. Income in retirement will depend on when the employee begins to contribute, how much the employee contributes, and the performance of the investments chosen.

Can future retirees rely on improvements in employer pensions to provide increased retirement income to offset potential reductions in Medicare and Social Security? The following observations can be used to address this question. First, only about half the labor force is currently covered by any type of employer pension and this proportion has remained at this level for the past 20 years. The current coverage rate and the stability of this rate over the past two decades indicate that many workers will not receive a company pension in retirement. Currently, only about 40 percent of elderly households do (Grad, 1998).

Second, coverage data clearly show that persons not accumulating pension credits are low wage and part-time workers. These workers are likely to become low income retirees, exactly those who are most dependent on Social Security and Medicare for their income and health insurance. They are unlikely to be able to afford to purchase additional medical insurance to replace cuts in Medicare. If women continue to have shorter, more 
irregular working careers, they will continue to accumulate less in defined contribution pension plans than comparable male workers.

Third, the trend toward increased availability of defined contribution plans has several potential implications for future retirement income. Workers who change jobs frequently accumulate lower retirement benefits when they move among firms with defined benefit plans. In contrast, job changes have relatively little impact on eventual retirement benefits of those in defined contribution plans. This implies that in the future, mobile workers may enter retirement with larger total pension benefits than in the past.

However, defined contribution plans place greater responsibility and investment risk on the individual worker. Most employees of firms providing defined benefit plans are automatically covered by the plan and they do not have to choose to reduce current income in order to save for retirement. In contrast, participants in many defined contribution plans must decide how much to contribute each pay period and how to invest their retirement funds. Selecting investments with low rates of returns will also lead to lower retirement benefits. Participants in these plans also may have access to the retirement funds prior to their retirement through loans or lump sum distributions at the time of job changes. If participants remove monies from their accounts, they will have lower benefits in retirement.

In summary, available evidence indicates that the proportion of workers who will receive pension benefits in retirement will remain about the same as today unless there are fundamental changes in national retirement and tax policies. Pension beneficiaries will continue to be among the wealthier retirees while future low income retirees will likely confront changes in Medicare without the benefit of employer-provided retirement income. For future retirees who have earned an employer pension, an increasing proportion of them will receive income from defined contribution pension plans, especially 401(k) plans. At present, the impact on pension income of participation in defined contribution rather than defined benefit plans is not known. More research is needed before we can accurately assess the impact of this trend. 
Retiree Health Insurance. Some firms offer health insurance coverage to both active and retired workers. Employer provided health insurance is a valuable benefit to workers and can influence the timing of retirement. Recent surveys indicate that the average cost per retiree for such coverage in 1996 was $\$ 5,210$ for retirees under the age of 65 and \$1,874 for persons 65 and over who were eligible for Medicare (EBRI, 1997). The value to retirees may exceed these company costs because the cost to the individual of purchasing similar private insurance would be much higher. Some companies terminate coverage for retirees at age 65 when they become eligible for Medicare.

Coverage by a company health insurance plan is a significant benefit for older persons and directly affects their economic well-being in retirement. The generosity of retiree health insurance is not linked to previous earnings as workers typically receive the same coverage regardless of their pre-retirement salary. Thus, for persons covered by these plans, retiree health insurance is relatively more important for low wage workers. Two significant questions emerge concerning retiree health insurance in the Twenty-First century. Will employer provided retiree health insurance be able to offset the reductions in Medicare so that retirees are able to retain the same level of health care? Will employer provided retiree health insurance be available to a higher percentage of future retirees? Existing evidence concerning the distribution of coverage, trends in the proportion of workers covered by these programs, and changes in the generosity of retiree health plans does not support the conclusion that retiree health plans will be able to alleviate cut backs in Medicare coverage.

Fewer than half of full-time workers are covered by retiree health insurance programs. Coverage rises with earnings, tenure, and firm size and is higher for unionized workers (EBRI, 1997). Thus, the retiree health insurance tends to increase the differences in economic well-being among retirees.

In addition to the decline in the proportion of the labor force covered by retiree health insurance plans, companies that have retained their plans have shifted a greater 
proportion of the cost to retirees. A large proportion of those plan sponsors now require workers to pay a portion of the cost of this insurance. As with their coverage for active workers, many companies have also changed their plans from traditional fee for service to some type of managed care plan.

Most retiree health plans are closely linked to Medicare by covering medical payments that are not reimbursed by Medicare. Reductions in Medicare coverage during the past decade have meant that company costs have risen. Higher costs coupled with expectations for further reductions in Medicare coverage may have also encouraged firms to reduce or eliminate their own health insurance coverage. The likelihood of future expansion of retiree health insurance is low. Further reductions in Medicare are more likely to exacerbate the decline in coverage than to stimulate employers to make up the difference in gaps in health care coverage.

\section{WORK AND RETIREMENT}

Most of the improvements in the economic well-being reported earlier occurred while the labor force participation rate of older persons was declining. Many analysts had anticipated that the trend toward earlier retirement would continue into the Twenty-First century. However, since the mid-1980s, the labor force participation rates of older American men have remained relatively stable and have actually increased during the last few years. Quinn (1999) has analyzed these changes and compared the actual patterns of labor force participation since 1985 with what would have occurred had the trend toward earlier retirement continued. The important conclusion is that the trend toward earlier and earlier retirement for American men ended over a decade ago.

The pre-1985 trends in labor force participation for older women were very different than those observed for older men reflecting the influence of two offsetting factors: a general trend toward earlier retirement and the increasing labor force participation of married women. For women aged 55 to 59, the net result was a very gradual increase in 
their participation rate from the mid-1960s to the mid-1980s while there was a gradual decline in the participation rate of women aged 60 and older. What is similar to the experience of men, however, is the dramatic change in trend in the mid-1980s (Quinn, 1999). The result is that many more older men and women are working today than the earlier trends would have predicted.

There are two possible conclusions for these observations. One is that we have reached the end of the era of earlier and earlier retirement. Specifically, more older persons are continuing to work in response to the outlawing of mandatory retirement, changes in Social Security rules, improved health, movement from manufacturing to service occupations, and the shift from defined benefit pension plans that encourage early retirement to defined contribution plans that are age neutral. An alternative hypothesis is cyclical - that we are observing a temporary pause in the inevitable trend toward earlier retirement because of a decade of substantial economic growth that improved the job prospects of older (and other) Americans. This implies that when the economy falters the trend toward earlier retirement will resume. Quinn (1999) attempted to test the validity of this "business cycle" hypotheses. His results indicate that the prosperity of the last decade was an important determinant of the labor force participation rate of older persons but that this explains only a small part of the post-1985 change. It appears that there is a new attitude toward continued employment among many older Americans.

The end of the early retirement trend of older men provides a note of optimism concerning the future. If a higher percentage of future cohorts work until age 65 or beyond, they will continue to have earnings and many would retain employer provided health insurance which would help offset reductions in Social Security benefits and Medicare coverage. Future changes in Social Security, Medicare, and employer pensions may provide further inducements for older persons to remain in the labor force. Already enacted changes in Social Security, such as the increase in the normal retirement age from 65 to 67 early next century, provide new incentives for older persons to remain in the labor 
force and delay the start of Social Security benefits. Future modifications in Social Security may alter retirement incentives further and change the relative attractiveness of work and leisure.

If the age of eligibility of Medicare is increased to match the higher normal retirement age for Social Security, this should also lead to later retirement. Other reductions in the generosity of Medicare payments would also encourage older persons to remain on the job, especially if they are covered by health insurance. The trend toward greater coverage by defined contribution plans will result in fewer workers being subject to the age-specific retirement incentives found in many defined benefit plans. Of course, employers must be willing to accommodate increased utilization of older workers and provide for meaningful employment opportunities. Whether employers will facilitate the employment of older persons or provide additional retirement incentives as government retirement incentives are reduced will be one of the most important questions in the first quarter of the Twenty-First century.

\section{FINAL ASSESSMENT}

The cost of providing retirement income and medical care to older Americans will increase dramatically in the next three decades due the aging of the population and will be compounded if medical prices continue to increase relative to other prices in the economy. The two largest public programs, Social Security and Medicare, are facing serious financial problems and both programs must be amended to restore their financial integrity. In general, changes in both programs are likely to reduce benefits for future elderly Americans. How these programs are changed will affect the future well-being of the elderly, especially low income elderly.

Are employer retirement programs likely to offset these potential reductions in public benefits? Based on current trends, we conclude that they are not. Employer pension coverage has remained relatively constant for two decades and it seems unlikely that there 
will be a dramatic increase in coverage during the next 20 years. Thus, we can anticipate that low wage workers and those with limited labor force participation will continue to enter retirement without the prospect of significant pension income. The implications of the ongoing shift towards greater use of defined contribution plans are, as yet, unknown. Some workers will accumulate a large retirement fund while others will not.

Company provided health insurance is one program that is directly linked to Medicare and the health care needs of older Americans. If Medicare reduces benefits, persons still enrolled in company plans could use this type of insurance to offset the loss in coverage. However, employer provided retiree health insurance coverage is declining. Employers are facing the same problems that are placing financial pressure on Medicare, an increase in the number of retirees and the increase in medical costs. These factors plus the reductions in Medicare that shift costs to company plans have raised the cost of providing retiree health insurance and resulted in fewer companies providing this benefit. Thus, it seems unlikely that employer provided retiree health insurance can be counted on to fill the Medicare gap.

SSI and Medicaid could be expanded to assist the low income elderly population and reduce the adverse impact of declines in Medicare benefits. It is important to note that the cost of these programs is projected to increase even if their current benefit rules are maintained, especially for Medicaid. Expansion of these programs requires the willingness of society to reallocate additional resources to the elderly and away from other national priorities.

Since 1985, the trend toward early retirement has abated and the labor force participation rate among older men in 1998 is about the same as it was in 1985. Does later retirement offer a method of coping with population aging and possible reductions in retirement benefits? Continued employment is consistent with improved health, greater life expectancy, and the need to moderate the increase in the ratio of beneficiaries to workers in Social Security and Medicare. If older persons remain on the job, they will continue to 
have earnings and many will retain health insurance coverage from their employers, thus reducing the impact of any benefit reductions in Medicare. Many of the likely changes in Social Security, Medicare, and employer pensions will encourage older persons to retire later.

A central question is whether employers would view this outcome as desirable and attempt to accommodate older workers who want to continue working. The answer will depend in part on the strength of the economy and the demand for labor in the future. Later retirement does provide an opportunity for some individuals to respond to benefit reductions in Social Security and Medicare. Others, however, burdened by poor health, outdated skills, or weak local labor markets will feel the full effect of any benefit reductions in Medicare and Social Security. 


\section{BIBLIOGRAPHY}

AARP Public Policy Institute. 1998. Boomers Approaching Midlife: How Secure a Future? Washington: American Association of Retired Persons.

Board of Trustees, Federal Hospital Insurance Trust Fund. 1999. 1999 Annual Report. Washington: USGPO.

Board of Trustees, Federal Old Age and Survivors Insurance and Disability Insurance Trust Funds. 1999. 1999 Annual Report. Washington: USGPO.

Board of Trustees, Federal Supplementary Medical Insurance Trust Fund. 1999. 1999 Annual Report. Washington: USGPO.

Burkhauser, Richard and Joseph Quinn. 1997. "Pro-Work Policy Proposals for Older Americans in the 21st Century," Syracuse University, Maxwell School, Policy Brief No. 9.

Clark, Robert and Ann McDermed. 1990. The Choice of Pension Plans in a Changing Regulatory Environment. Washington: American Enterprise Institute.

Employee Benefit Research Institute. 1994. Employment Based Retirement Income Benefits: Analysis of the April 1993 CPS, Issue Brief No. 153. Washington: EBRI.

Employee Benefit Research Institute. 1997. EBRI Databook on Employee Benefits. Washington: EBRI.

Grad, Susan. 1998. Income of the Population 55 or Older, 1996. Social Security Administration, Office of Research, Evaluation and Statistics, SSA Publication No. 1311871. Washington: USGPO.

Gustman, Alan and Thomas Steinmeier. 1992. "The Stampede Towards Defined Contribution Plans," Industrial Relations 31: 361-69.

Hustead, Edwin. 1998. "Trends in Retirement Income Plan Administrative Expenses," in Olivia Mitchell (ed.), Living With Defined Contribution Pensions. Philadelphia: University of Pennsylvania Press, pp. 166-177.

Ippolito, Richard. 1997. Pension Plans and Employee Performance. Chicago: University of Chicago Press.

McNeil, John. 1998. Changes in Median Household Income: 1969 to 1996. Current Population Reports, Series P-23, No. 196. Washington: USGPO.

Moon, Marilyn. 1996. Medicare Now and in the Future. Washington: Urban Institute, second edition.

Olsen, Kelly and Jack VanDerhei. 1997. Defined Contribution Plan Dominance Grows Across Sectors and Employer Sizes, While Mega Defined Benefit Plans Remain Strong. Employee Benefit Research Institute Issue Brief, No. 190. Washington: EBRI. 
Quinn, Joseph. 1999. Retirement Patterns and Bridge Jobs in the 1990s. Employee Benefit Research Institute Issue Brief No. 206. Washington: EBRI.

Sabelhaus, John and Joyce Manchester. 1995. "Baby Boomers and Their Parents: How Does Their Economic Well-Being Compare in Middle Age," Journal of Human Resources 30(4):791-806.

Schieber, Sylvester and John Shoven. 1997. "The Consequences of Population Aging on Private Pension Fund Saving and Asset Markets," Sylvester Schieber and John Shoven (eds.), Public Policy Towards Pensions. Cambridge, MA: The MIT Press, pp. 219-46.

U.S. Bureau of the Census. 1992. Measuring the Effects of Benefits and Taxes on Income and Poverty: 1979 to 1991. Current Population Reports, Series P-60, No. 182RD. Washington: USGPO.

U.S. Bureau of the Census. 1997. Poverty in the United States: 1996. Current Population Reports, Series P-60, No. 198. Washington: USGPO.

U.S. Department of Labor. 1994. Pension and Health Benefits of American Workers. Washington: USGPO.

U.S. House of Representatives, Committee on Ways and Means. 1998. 1998 Green Book. Washington: USGPO.

U.S. Office of the President. 1999. Economic Report of the President. Washington: USGPO.

Wolff, Edward N. 1998. "Recent Trends in the Size Distribution of Household Wealth," The Journal of Economic Perspectives 12(3): 131-150.

\footnotetext{
${ }^{1}$ For example, the labor force participation rate of men aged 65 declined from 50 percent in 1970 to 33 percent in 1996 and the participation for men aged 68 fell from 38 percent to 23 percent during the same period (Burkhauser and Quinn, 1997).

${ }^{2}$ Using the broader measure of income mentioned above and the same poverty thresholds, there is less elderly poverty -- both in absolute terms and relative to the rest of the population. For instance, among those aged 65 and over, the 1996 poverty rate drops almost in half from 11 to 6 percent. With the same change in definition, the overall poverty rate drops from 14 to 9 percent, a more modest decline of one-third (U.S. Bureau of the Census, 1997).

${ }^{3}$ These data may understate the importance of pensions, since the income derived from the distributions of defined contribution pension proceeds may be listed under "income from assets," even though these assets were accumulated in a pension program.

${ }^{4}$ Of this expenditure, about 87 percent went to retirees and survivors, and the other 13 percent went to disabled beneficiaries (Board of Trustees, OASDI, 1999). Medicare expenditures equaled another 12 percent of the federal budget in fiscal year 1998 (U. S. Office of the President, 1999).
} 
${ }^{5}$ In 1999 , the PIA is calculated using 90 percent of the first $\$ 505$ of AIME, plus 32 percent of the next $\$ 2,538$, plus 15 percent of any AIME over $\$ 3,043$.

${ }^{6}$ The financial projections are presented each year by the OASDI Board of Trustees. The estimates used in this paper are the Trustees' intermediate projections.

${ }^{7}$ The SSI program was established in 1972, and became operational in January of 1974. SSI replaced the Federal-State programs of Old-Age Assistance, Aid to the Blind and Aid to the Permanently and Totally Disabled (U.S. House, 1998: 262).

${ }^{8}$ This amount represents the average expenditure per HI enrollee plus the average expenditure per SMI enrollee (Board of Trustees, Federal Hospital Insurance Trust Fund, 1999; Board of Trustees, Federal Supplementary Medical Insurance Trust Fund, 1999).

${ }^{9}$ The proportion of active pension participants with primary coverage in a defined contribution plan increased from only 13 percent in 1975 to 42 percent in 1997 (Olsen and VanDerhei, 1997).

${ }^{10}$ The increase in relative cost has fallen most heavily on small firms (Hustead, 1998) and as a result, the decline in the use of defined benefit plans has been greatest among these firms. In addition, structural changes in the economy, such as increased employment in the service sector and in smaller firms and changes in the composition of the labor force to include more mobile workers, have also affected the trend toward greater use of defined contribution plans (Gustman and Steinmeier, 1992; Ippolito, 1997). 